\title{
Exhumations: rarely done procedure but useful in many circumstances-a review of 47 cases in Nigeria
}

\author{
Wilson Oberaifo Akhiwu ${ }^{1 *}$ and Chukwuemeka Charles Nwafor ${ }^{2}$
}

\begin{abstract}
Background: To do a comprehensive analysis of all exhumation and post mortem examination (EPME) performed in South-South region of Nigeria, with an aim to determine the causes of death and various factors that affect it.

Methodology: This is a retrospective study of all EPME that were done in South-South region of Nigeria over 16 years (1 January 2001 and 31 December 2017). The duplicate copies of all EPME reports that were written previously and police reports for each case were reviewed.

Results: A total of 47 cases were seen. The youngest case was a 6-month-old male and the oldest an 86-year-old man. Males accounted for $72.3 \%$ of cases. Age group 20-29 years accounted for most (19.1\%) cases. The history summary included sudden traumatic death (40.4\%), bodies found floating on the river (23.4\%), and kidnapped victims (8.5\%). In 91.5\% of cases, the autopsies were performed immediately after exhumation beside the grave. Grave locations were the river bank (23.4\%), farm lands (21.3\%), the deceased family compound (21.3\%), cemetery (17\%), and in the forest (10.6\%). Two mass graves were seen containing 8 bodies and 11 bodies, respectively. A casket was used in 9 cases (19.1\%). The shortest interval between burial and exhumation was 5 days, and the longest interval was 348 days. On exhumation, the remains were moderately to severely decomposed (36.2\%), skeletonized (34\%), or partially decomposed (23.4\%). The causes of death were seen in $63.8 \%$ of cases.

Conclusion: Exhumation, though rarely done, still remains a useful procedure, because in a significant number of cases, it helped to answer the medico-legal question (the causes of death were seen). Young males account for most cases in our setting.
\end{abstract}

Keywords: Exhumation, Post mortem examination, Grave, Exhumed body, Manner of death

\section{Introduction}

Exhumation in the forensic pathology is the act of lawfully bringing out a buried dead human body for medicolegal purposes (Williams and Davison 2014). This process most times is followed by performing a post mortem examination on the body, so as to find out the pathogenesis and pathophysiology of events that lead to the death. Apart from finding out the cause and manner of death, other circumstantial evidence can be seen from a well-performed exhumation and post mortem examination (EPME). It is also performed for establishment of

\footnotetext{
*Correspondence: Wilson.akhiwu@yahoo.com

'Department of Histopathology, University of Benin Teaching Hospital, Benin City, Edo State, Nigeria

Full list of author information is available at the end of the article
}

identity, belated suspicion of an unnatural death, or due to medical insurance problems (Williams and Davison 2014; Bardale et al. 2012; Kremer and Sauvageau 2008; Karger et al. 2004). A previously autopsied and buried body can also have EPME. This could be done as a repeat (second autopsy), in situations where the deceased relatives feel that there is an act of negligence by the doctor when the deceased was on treatment, or due to suspicion that police investigations were improper or the relatives feel that the first autopsy was not properly done (Bardale et al. 2012). Other not so popular indications for exhumations are relocation of the remains, say in a case of urban redevelopment for example, or in order to answer archeological or historical or cultural questions (Guimaraes et al. 2017). In these later groups, post 
mortem examinations are not done. Lately, EPME has been proven to be an instrument for the evaluation of the quality of death certificates previously issued and previous death investigations carried out (Karger et al. 2004). About 37\% discrepancy has been shown to exist between EPME findings and documented causes of death on certificates (Karger et al. 2004). EPME is broadly divided into 2 major groups: EPME for legally and lawfully interred bodies and EPME for unlawfully interred bodies (which are usually cases of homicides) (Kremer and Sauvageau 2008). EPME rate is indirectly proportional to the rate of autopsy of a locality (Guimaraes et al. 2017).

Important steps in EPME include detailed history of event, taking note of the following: scene of the grave, type of grave, whether the earth over the grave is fresh or old, the size of the grave (length, width, and depth), number of bodies in the grave, use of a casket or not, position of the body in the grave, condition of the body, and the post mortem examination (PME) proper. EPME is not commonly done compared to ordinary PME, due to the following reasons: most PME are done correctly (hence reducing the need for EPME), religious and cultural belief of the people, lack of in-depth knowledge of it by the security agencies, financial involvement, and in some situations, expertise and competence of the pathologist (Guimaraes et al. 2017; Faduyile et al. 2015; Kumar et al. 2011).

Previous studies in Canada, Germany, Brazil, Kosovo, India, Pakistan, Tunisia, and Nigeria have documented the importance of EPME (Bardale et al. 2012; Kremer and Sauvageau 2008; Karger et al. 2004; Guimaraes et al. 2017; Faduyile et al. 2015; Kumar et al. 2011; Ammani et al. 2016; Asad et al. 2014; Agarwal et al. 2017; Nouma et al. 2016; Nnoli et al. 2013; Sprogoe-Jakobsen et al. 2001). In Nigeria, after an extensive literature search, only two publications on EPME were seen. A presentation of 2 cases by Faduyile et al. 2015 and 8 cases by Nnoli et al. 2013.

Due the importance of EPME in the justice system, the authors have tried to present EPME performed in the South-South region of Nigeria, with the aim of making a comprehensive analysis of all EPME performed by the authors.

\section{Methodology}

This is a retrospective study of all EPME that were done in South-South region of Nigeria over 16 years (1 January 2001 and 31 December 2017). In all EPME, the coroner mandated the pathologist to perform the procedure. The duplicate copies of all EPME reports that were written previously and police reports for each case were reviewed. PME were performed immediately after exhumation in all cases except on 3 occasions when exhumation finished late and the PME were done the following day. Standard procedures as much as possible were followed and the various findings ranging from basic history, demographic parameters, grave adequacy, and post mortem findings were analyzed by using Statistical Package for Social Science (SPSS) version 23. A $p$ value of $\leq 0.05$ was taken to be significant. For each case, judicial approval was gotten from the coroner before the process. The team for each case, composed of 2 trained diggers, 2 morticians, a photographer, a police officer (investigating police officer), and at least 2 pathologists. At arrival at the burial site, the suspected grave is cordoned off, grave area is observed, appropriate dimensions taken, and other circumstantial evidence numbered/tagged and photographed. The soil excavation is meticulously done until the body or casket is met/sighted. At this point, more caution is applied to get all necessary evidence, before the body is carried gently out of the grave. By the side of the grave, the body is kept on a clean mat on a table in most cases except the few cases where a body bag was used in transporting the body to the morgue. The body is cleaned up and autopsied proper using mostly the Ghon's method of organ evisceration. Also done routinely was tissue histology while toxicology and X-ray were occasionally done. Throughout the whole process, photographs are taken with proper name tags. The findings are as presented in various tables below. None of these EPME except one was a repeat autopsy. All EPME were included (none was excluded).

University of Uyo Teaching Hospital, Uyo Institutional Health Research Ethical Committee (IHREC), gave approval for this study, with approval certificate number UUTH/AD/S/96/VOL.XXI/251.

\section{Results}

A total of 47 exhumed bodies (EB) were seen between 2001 and 2017. The youngest EB was a 6month-old male and the oldest an 86-year-old man, with a mean age of $37.44 \pm 22.78$. Table 1 shows the age, sex, summary of history, and the autopsy venue for the individual EB. In $40.4 \%(n=19)$ of EB, the history summary was mainly of sudden traumatic death followed by burial. These included EB of sudden blunt head injuries, fire explosion, and gun shots. In $23.4 \%(n=11)$ of EB, the bodies were seen floating on the river early in the morning and natives retrieved them and buried them by the river bank to avoid contamination of their water.

Table 2 shows various parameters in relation to the grave. They EB were either buried by the river bank $(23.4 \%, n=11)$, farm lands $(21.3 \%, n=10)$, or the deceased family compound $(21.3 \%, n=10)$. In $17 \%(n=8)$ of $\mathrm{EB}$, they were buried in the cemetery and in the forest 
Table 1 Age, sex, history of cases, and venue of autopsies

\begin{tabular}{|c|c|c|}
\hline Sex & No of cases & Percentage (\%) \\
\hline Male & 34 & 72.3 \\
\hline Female & 13 & 27.3 \\
\hline \multicolumn{3}{|l|}{ Age group (available for 35 cases) } \\
\hline $0-9$ & 3 & 6.4 \\
\hline $10-19$ & 5 & 10.6 \\
\hline $20-29$ & 9 & 19.1 \\
\hline $30-39$ & 3 & 6.4 \\
\hline $40-49$ & 4 & 8.5 \\
\hline $50-59$ & 3 & 6.4 \\
\hline $60-69$ & 5 & 10.6 \\
\hline $70-79$ & 2 & 4.3 \\
\hline$\geq 80$ & 1 & 2.1 \\
\hline \multicolumn{3}{|l|}{ Summary of history } \\
\hline $\begin{array}{l}\text { Sudden traumatic death followed } \\
\text { by burial }\end{array}$ & 19 & 40.4 \\
\hline $\begin{array}{l}\text { Bodies found floating on a river } \\
\text { and buried }\end{array}$ & 11 & 23.4 \\
\hline Sick, died, and buried & 6 & 12.8 \\
\hline Someone accused & 5 & 10.6 \\
\hline Kidnapped victims & 4 & 8.5 \\
\hline Shot by police & 1 & 2.1 \\
\hline $\begin{array}{l}\text { Second exhumation after an unskilled } \\
\text { exhumation }\end{array}$ & 1 & 2.1 \\
\hline \multicolumn{3}{|l|}{ Autopsy venue } \\
\hline Grave site & 43 & 91.5 \\
\hline Mortuary & 4 & 8.5 \\
\hline
\end{tabular}

in $10.6 \%,(n=5)$ of situations. Two mass graves were seen in this series, containing 8 bodies and 11 bodies, respectively.

Table 3 shows the time elapsed between burial and exhumation, condition of the body before burial, condition of body on exhumation, manner of death, and the different causes of death seen after the autopsy. Majority of the bodies $(78.7 \%, n=37)$ were not preserved (either by refrigeration or formalin embalmment) before they were buried. On exhumation, $36.2 \%(n=17)$ of the bodies were moderately to severely decomposed. Skeletonized remains were seen in $34 \%(n=16)$ of EB, while in $23.4 \%$ $(n=11)$ of EB, partial decomposition was seen. Facial recognition was possible in only $25.5 \%(n=12)$ of EB (though facial recognition is not a standard primary identifier, compared to genetics, odontology, and finger printing which are not done in Nigeria). However, identification was of less importance in the cases seen. A correlation between the duration of the body in the ground and the condition of the body on exhumation gave a $p$ value of 0.018 .
Table 2 Parameters in relation to the grave

\begin{tabular}{|c|c|c|}
\hline Variable & No of cases & Percentage (\%) \\
\hline \multicolumn{3}{|l|}{ Grave site } \\
\hline River bank & 11 & 23.4 \\
\hline Farm land & 10 & 21.3 \\
\hline Deceased compound & 10 & 21.3 \\
\hline Cemetery & 8 & 17.0 \\
\hline Forest & 5 & 10.6 \\
\hline Others & 3 & 6.3 \\
\hline \multicolumn{3}{|l|}{ Grave type } \\
\hline Single grave & 28 & 93.3 \\
\hline Mass grave & 2 & 6.7 \\
\hline \multicolumn{3}{|l|}{ Grave condition } \\
\hline Relatively fresh & 29 & 61.7 \\
\hline Fresh & 8 & 17.0 \\
\hline Old & 6 & 12.8 \\
\hline Tomb & 2 & 4.3 \\
\hline Altered & 1 & 2.1 \\
\hline Cemented top & 1 & 2.1 \\
\hline \multicolumn{3}{|l|}{ Grave adequacy } \\
\hline Adequate & 13 & 27.7 \\
\hline Inadequate & 34 & 72.3 \\
\hline \multicolumn{3}{|l|}{ Presence of casket } \\
\hline Casket used & 9 & 19.1 \\
\hline Casket not used & 38 & 80.9 \\
\hline
\end{tabular}

Others include uncompleted house (Ammani \& Sai Sudheer, 2016) and disused pit and swamp

Figure 1 shows a scene of exhumation and major autopsy finding (multiple skull fractures) in the 21-year-old lady that was abducted, raped, killed, and buried.

Figures 2 and 3 are from the scenes of EPME of a 41year-old man that was involved in a road traffic accident. Autopsy was not done before the burial, hence the exhumation. The major findings were massive hemothorax from the fractured ribs that lacerated the lungs.

Figures 4 and 5 are scenes from the EPME of a 78year-old male that was missing for 3 days, and a search team in the community saw a suspected grave in a nearby uncompleted house and informed the coroner through the police.

Figures 6 and 7 are EPME of a 22-year-old male that was abducted during a funeral wake keep service by rival cult group. The body was retrieved in a swamp (proper exhumation digging not done because of the site), in a big sac, buried vertically with the head leading. Though the exact cause of death was not seen, the body was seen tied up severally with a thick rope, with the upper limbs behind. With this finding, a suspect arrested later attested to. 
Table 3 Duration of body underground, condition of body on exhumation, and cause of death

\begin{tabular}{|c|c|c|}
\hline Variable & No of cases & Percentage \\
\hline \multicolumn{3}{|l|}{ Condition of body before burial } \\
\hline Embalmed & 6 & 12.8 \\
\hline Not embalmed & 37 & 78.7 \\
\hline Not sure & 4 & 8.5 \\
\hline \multicolumn{3}{|c|}{ Duration of body in the ground (available for 32 cases) } \\
\hline $1-6$ days & 1 & 2.1 \\
\hline $7-13$ days & 5 & 10.6 \\
\hline 14-21 days & 6 & 12.8 \\
\hline $22-49$ days & 16 & 34 \\
\hline $50-84$ days & 3 & 6.4 \\
\hline $85-180$ days & 1 & 2.1 \\
\hline$>180$ days & 1 & 2.1 \\
\hline Unknown duration & 14 & 29.9 \\
\hline Condition of body & No of cases & Percentage (\%) \\
\hline Moderate to severe decomposition & 17 & 36.2 \\
\hline Bony remains & 16 & 34.0 \\
\hline Mild decomposition & 11 & 23.4 \\
\hline Charred body & 2 & 4.3 \\
\hline Fresh & 1 & 2.1 \\
\hline \multicolumn{3}{|l|}{ Facial recognition } \\
\hline Possible & 12 & 25.5 \\
\hline Not possible & 35 & 74.5 \\
\hline \multicolumn{3}{|l|}{ Manner of death } \\
\hline Homicide & 18 & 38.3 \\
\hline Natural & 6 & 12.8 \\
\hline Accident & 5 & 10.6 \\
\hline Suicide (by hanging) & 1 & 2.1 \\
\hline Undetermined & 17 & 36.2 \\
\hline \multicolumn{3}{|l|}{ Homicide cases } \\
\hline Skull fractures & 10 & 55.6 \\
\hline Rifle gunshot & 3 & 16.7 \\
\hline Shot gun & 1 & 5.5 \\
\hline Others & 4 & 22.2 \\
\hline \multicolumn{3}{|l|}{ Accident } \\
\hline Fire explosion & 3 & 60 \\
\hline Electrocution & 1 & 20 \\
\hline Road traffic accident & 1 & 20 \\
\hline
\end{tabular}

Others include a case each of stab wounds, multiple rib fractures, cervical vertebrae fracture, and a case of tied up with thick rope, dumped in a sac bag, and buried head down

\section{Discussion}

The commonest history gotten from relatives was that of sudden traumatic death followed by burial and bodies found floating on the water that were retrieved and buried by the river bank, before the coroner's mandate for EPME.

Most cases were financed by the relatives of the deceased and due to financial constraints, $91.5 \%$ of the PME were performed by the grave sides. Only the study by Sprogoe-Jakobsen et al. (2001) in Kosovo made mention of PME venue, in which the PME were not done in autopsy suites, but on different types of surfaces (including plastic apron on the ground, horse-carts, picnic tables, and wooden tables) and non-availability of water. Though cheaper for the financers, PME by the grave side were more tedious because they are not proper autopsy settings and usually posed more challenges for the pathologist and his assistants. A fact agreed by SprogoeJakobsen et al. (2001). We do not rule out the fact that some (though few) facts may have been missed. Its major advantage is that for all cases, the pathologist was present and conducted/supervised the exhumation (thereby protecting against wrong exhumation technique since our assistants in this part of the world do not have formal education, training, or exposure for such a procedure). The pathologist is the contact person for the investigating agency and only his/her report is honored. In Quebec, Canada, in $37.5 \%$ of situations, the pathologist was not at the scene of the exhumation (Kremer and Sauvageau 2008).

Normally mass graves are rarely used except in mass disasters. Even in such situations, the bodies are first placed in separate well-tagged body bags, buried in trenches, parallel to each other and never stacked together in an overcrowded grave (Cordner et al. 2016). In such situations, these mass graves are properly marked above the ground and tracked for future reference and identification of remains when the logistics are available. Of the 2 mass graves seen in the index study, their bodies were not put in separate body bags, they were not buried in trenches (bodies were kept on top of each other) nor were the graves marked or tracked. For the mass grave containing 8 bodies, they were almost completely decomposed; however, the skulls showed evidence of traumatic skull fracture and an eye witness (a surviving family member) confirmed the number of people that were buried. Normal burial areas depending on culture and religion in our setting include the following: deceased compound/house, farmlands, and cemeteries. Riverbank is not an ideal burial area, but in the index study, it was seen in $23.4 \%$ of cases $(n=11)$. A mass grave containing 11 bodies was situated by the riverbank, because these unidentified bodies were seen floating on the river and locals/users of the river wanted to avoid polluting their source of water, retrieved the bodies and buried them by the riverbank. The recovery and removal of the bodies from the riverbank helped to prevent the imagined water pollution. Hence, the EPME helped to save the community. Eight cases in the 


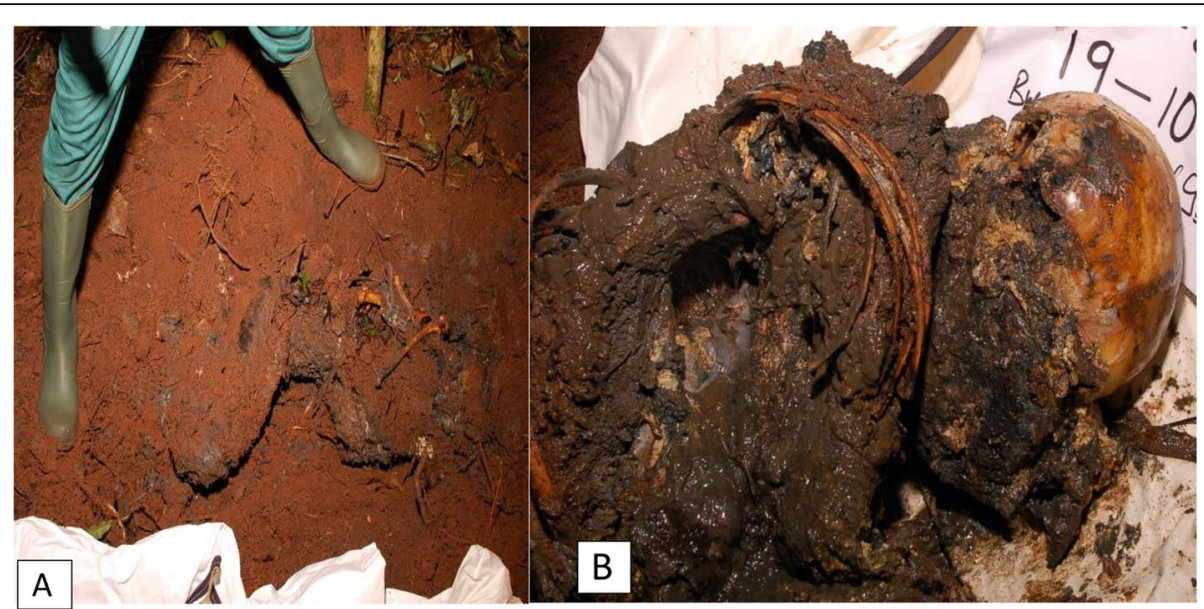

Fig. 1 a Body of the 21-year-old lady seen flexed at the knee and forced into the small grave. b Right occipitotemporal skull fractures with decomposed internal organs

index study were buried in the forest, uncompleted house, and disused pit. These were kidnap and cultism-related deaths. This confirms the known fact that exhumations carried out at remote places are usually secret disposals, and the outcome will be violent death of homicidal intention. This contrasts exhumations in notified areas (regular graveyards) where the outcome are either suicide or accident or natural death (Saukko and Knight 2004).

An ideal grave should have a depth of $180 \mathrm{~cm}(1.8 \mathrm{~m})$. But in recent times, a depth of $129.54 \mathrm{~cm}$ is accepted, such that coffin takes $38.1 \mathrm{~cm}$ and $90 \mathrm{~cm}$ is left above the coffin, to contain sand (Wikipedia 2018). The ideal grave should be free from water or hard rock. There was significant correlation $(P=0.025)$ between grave adequacy and the history summary. The presence of 2 not properly arranged mass graves contributed significantly (since it accounted for more than $40 \%$ of cases $(n=19)$. Most of the graves in the index study were inadequate. This could be closely tied to the summary of history of individual cases. Majority were hurriedly done, either to prevent a suspected pollution, to cover a kidnapped case gone sour, or due to a sudden traumatic death. The reasons above also explain why a casket was rarely used, despite the fact that these EPME were done in areas where it is cultural habit to bury with a casket. This finding also collaborates with that of Ammani et al. (2016) that opined that shallow graves (depths of 30 to $60 \mathrm{~cm}$ ) usually indicated hurried disposal in secrecy by perpetrators so as to conceal a crime.

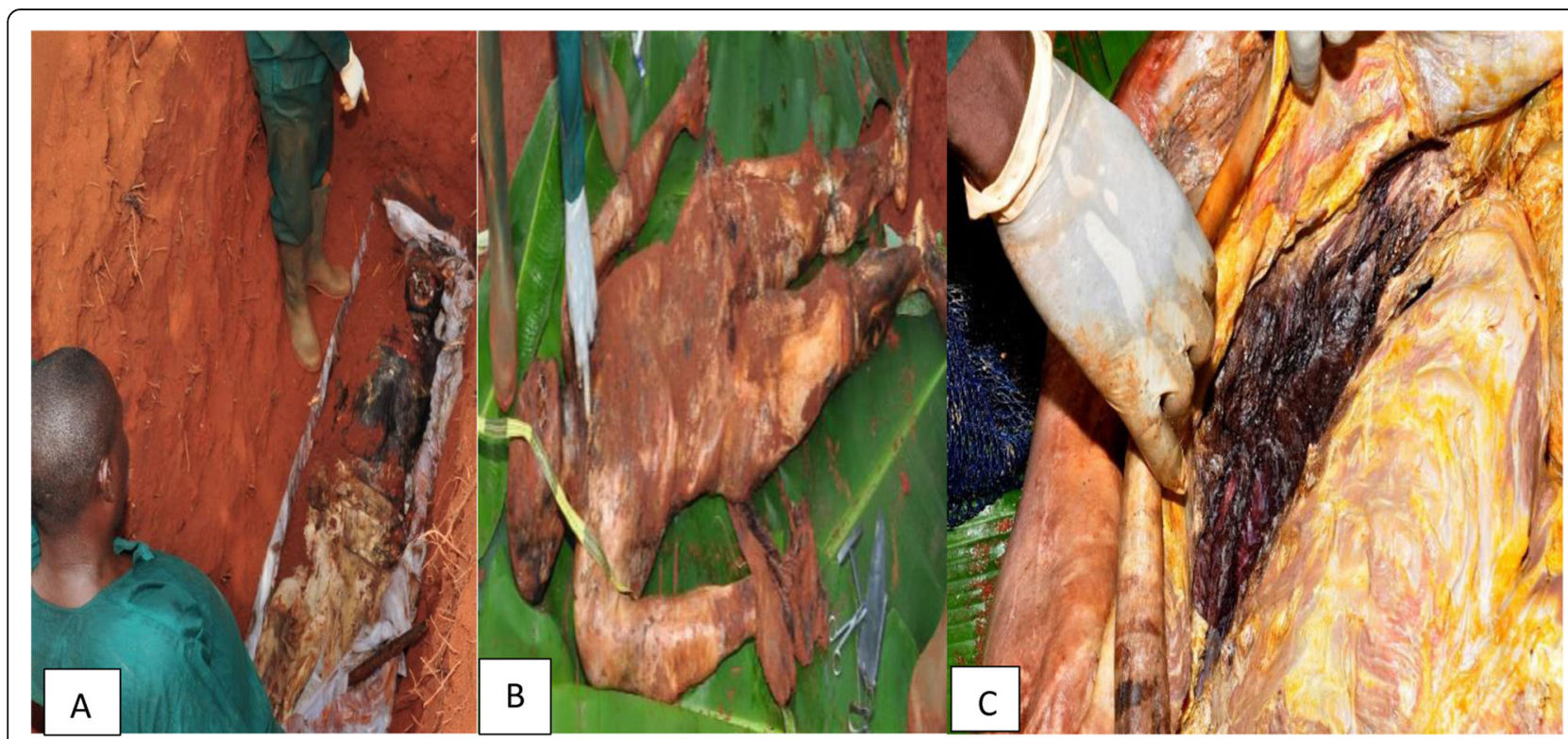

Fig. $\mathbf{2}$ a The decomposing body inside a casket that all the sides are giving away (disintegration). b Body on the surface, about to be autopsied. c Chest injuries 


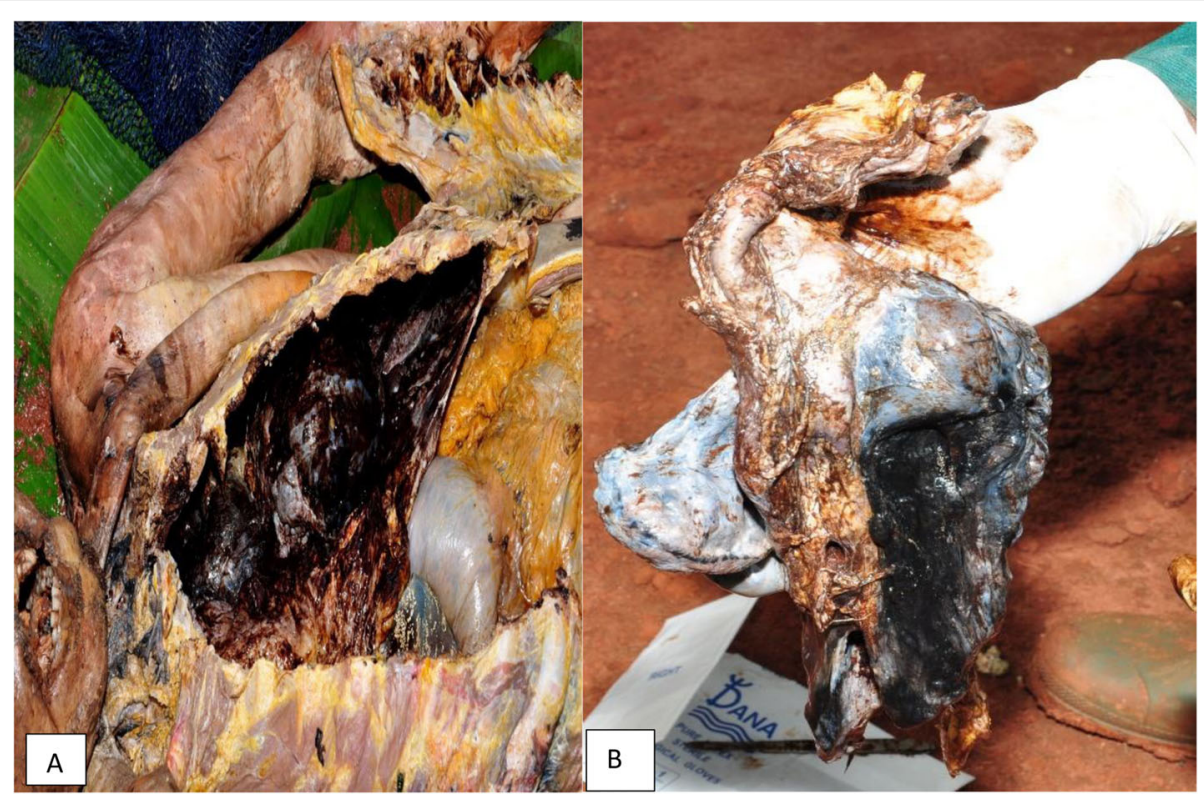

Fig. 3 a Massive left hemothorax. b Lacerated and collapsed left lung

A correlation of the grave condition (mainly subjective assessment of the soil covering the grave) and the condition of the body on exhumation was not significant $(P=0.086)$. Hence, the standard way (forensic archeology) remains the best option.

Most of these EPME were done in parts of the country where dead bodies are usually preserved by formalin embalmment before burial. However, a significant observation in this study is that in most cases $(78.7 \%, n=37)$, no form of preservation was done. This observation may not be unconnected with the history surrounding the deaths. Except for skeletonized bodies in mass graves, identification is not usually a major problem in EPME, because in many occasions, the complainants/relatives are usually sure of the grave sites except in kidnap cases. When in doubt of identification, DNA profiling of the long bones and teeth have

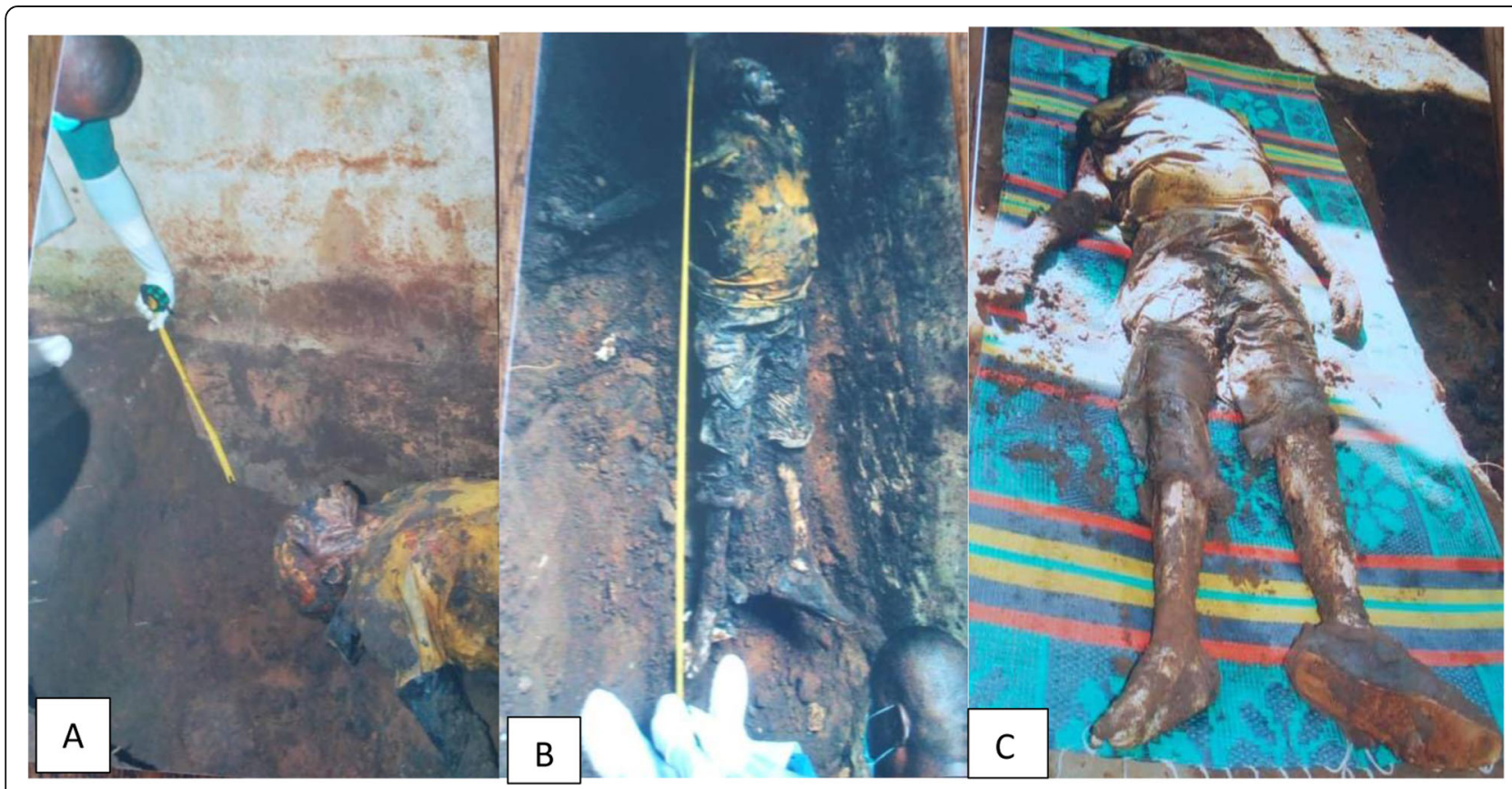

Fig. 4 a, b Body seen facing up and not in a casket. c After complete exhumation 


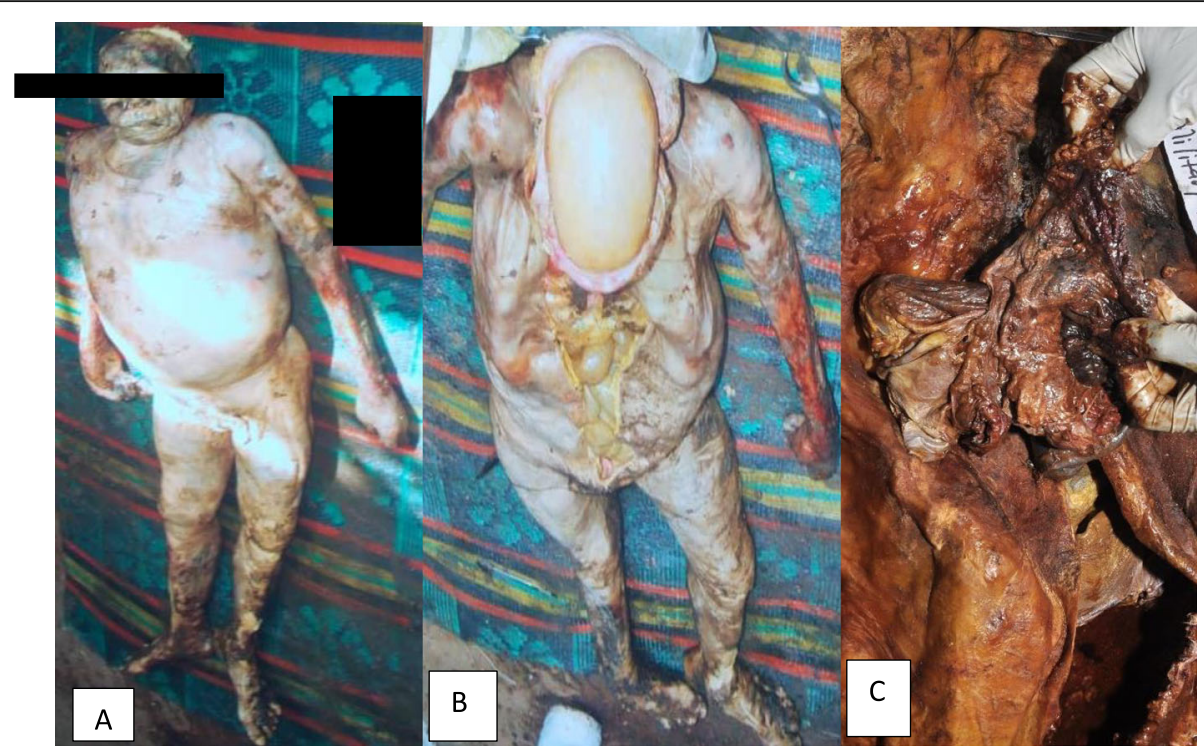

Fig. 5 a After cleaning up. b, c Opening up

given excellent results, though identification was not an issue in the index study and none was done in our series (Ammani et al. 2016; Nouma et al. 2016).

All 47 cases except 1 were exhumed within 6 months of burial. This is similar to observations in previous studies in Quebec, Canada, and Munster, Germany, where most EPME were done within a year of burial (Kremer and Sauvageau 2008; Karger et al. 2004). In Kosovo, the interval was up to a year and 6 months (Sprogoe-Jakobsen et al. 2001). The likelihood of success of an EPME depends on the extent of morphological changes, post-mortem decay, and the object that caused the injury, including the part of the body injured. A lot of changes ranging from mechanical to chemical erosion due to the effects of soil and the action of predators and plants usually occur on the buried body (Saukko and Knight 2004). Despite these changes, a lot of information can be obtained even when the body has been buried for months or even years. A significant correlation $(P=0.018)$ was observed between the duration of the body in the ground and the condition of the body on exhumation. This is similar to findings by Bardale et al. 2012; Ammani et al. 2016; Asad et al. 2014; and SprogoeJakobsen et al. 2001. The majority were either moderately to severely decomposed or were bony remains. The major

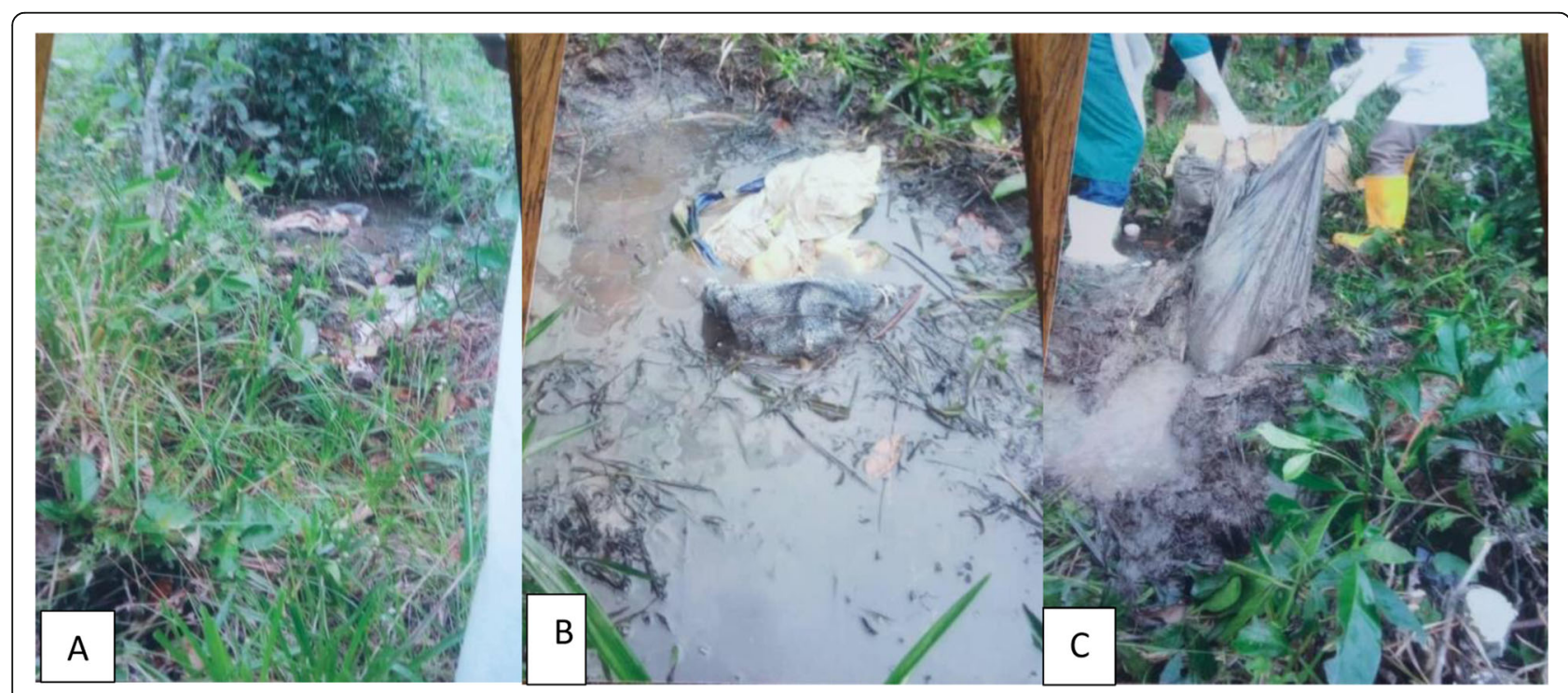

Fig. 6 a Grave in a swamp. b Closer shot after cutting surrounding grass. c Pulling out a sac bag containing the body. Digging to expose body was not possible because of swampy nature 


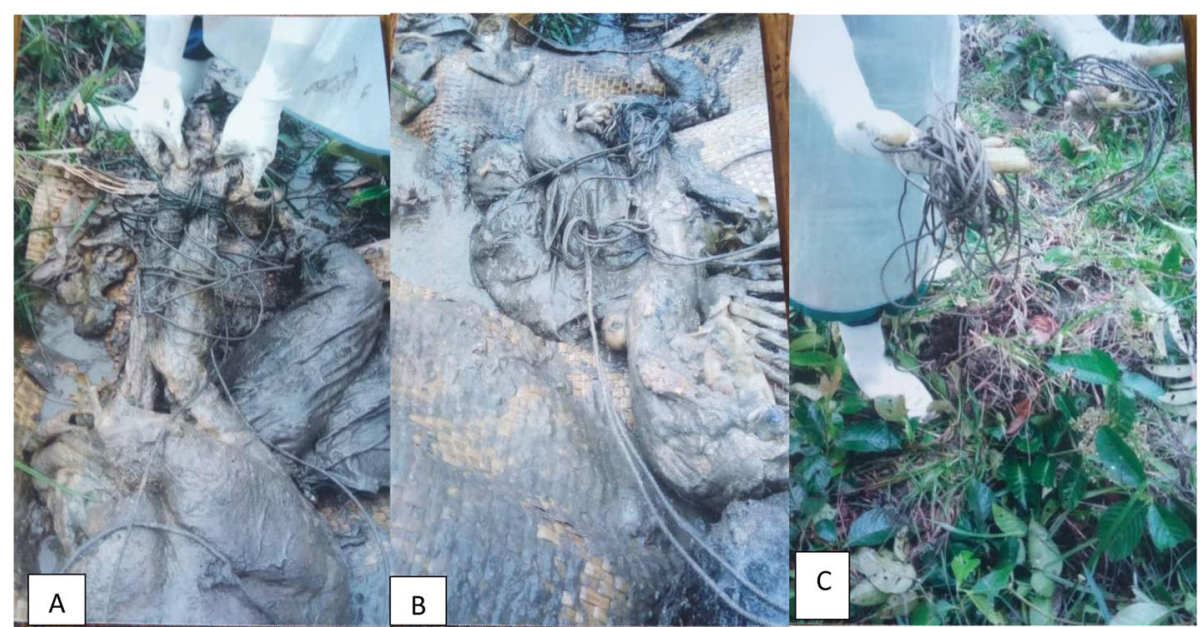

Fig. 7 a Legs and ankle tied up severally. b Thigh tied up. c Full length of rope used

disadvantage of delayed exhumation is the loss of significant information (especially soft tissue injuries) (Bardale et al. 2012; Kumar et al. 2011; Nouma et al. 2016). In moderate to advanced stages of decomposition, their marks of violence on the soft tissue are usually lost. Organs will also be in various stages of decomposition, such that tissue histopathology will be of little assistance (Agarwal et al. 2017). Loss of the soft tissue also hinders the proper interpretation of findings (Nouma et al. 2016). A major cause of delay in exhumation in our setting is the duration it takes before culprits/suspects in kidnap/cultism cases who usually give information about the location are found. Another major factor is the issue of financing. In Nigeria, most cases of EPME are financed by the relatives of the deceased. In Pakistan, the major reasons for delay in EPME are the fear of the living that the procedure is a dishonor to their late dear ones and due to lengthy legal procedures before an approval to do EPME is given (Asad et al. 2014). Many factors like the nature of terminal illness, season of burial, burial practice, presence of coffin or other protective means, nature and temperature of the soil, and the duration of post mortem interval determine the condition of the body on exhumation (Bardale et al. 2012; Saukko and Knight 2004). In Germany, the mostly low temperature helps in preserving the body, whereas in Pakistan, hot climate, water logging of graves, salinity, and improper drainage of graveyards quickens decomposition (Karger et al. 2004; Asad et al. 2014).

Based on the manner of death classification, all deaths could be accidental, homicidal, suicidal, natural, or undetermined (Hanzlick et al. 2002). EPME do not always provide the answer to the cause of death/manner of death in all circumstances. Many authors reported an undetermined/inconclusive EPME in their various works. The manner of death was undetermined in $36.2 \%$ of cases in this series, mainly due to advanced decomposition and no bony injury seen. Though, this does not rule out severe soft tissue injuries of any pathology or natural causes of death. The index rate of $36.2 \%$ is within the range of $15.5 \%, 33.4 \%, 33.5 \%$, and $34.4 \%$ observed in Sindh, Pakistan; interior of Sindh, India; Nagpur, India; and Munster, Germany, respectively (Bardale et al. 2012; Karger et al. 2004; Kumar et al. 2011, Agarwal et al. 2017). However, due to the marked difference in sample size in the various studies, this linear generalization of undetermined cases may not holistically apply. The sample size in Germany was the highest (155 cases) and had a lower number of decomposed cases due to delayed putrefaction of corpse because of cold season in many months of year and application of sophisticated diagnostic techniques like immunocytochemistry (Karger et al. 2004). The rate of $36.2 \%$ is very significant; hence, some practitioners feel that exhumations are of little help in medicolegal investigations. A trained criminal might delay showing a burial site for long duration, with an aim to reveal it when he/ she feels that a body "say strangulated or choked body might have decomposed enough. However, even negative EPME that reveals only bony remains without fracture or any bony lesion has answered a medicolegal question to an extent (Saukko and Knight 2004).

Homicidal deaths were most commonly seen, similar to previous studies (Bardale et al. 2012; Karger et al. 2004; Nnoli et al. 2013; Sprogøe-Jakobsen et al. 2001). Skull fracture was the most common pattern of homicide seen, distantly followed by gunshots. At times, the exact cause of death was not seen but associated death events like tying up was seen.

Toxicological investigations were done in 3 cases and were all negative. Due to the small number, no logical conclusion could be extrapolated from it. Duration of body in the grave may have contributed to no poison detection. 


\section{Limitations}

Imaging studies were not routinely done, except for 2 cases of bony remains. The majority of the PME were by the graveside. Toxicology was done in only 3 cases, while immunohistochemistry was not done in any case. Anthropologist was not involved in any of the exhumations.

\section{Conclusion}

An extensive analysis of exhumation from a Nigeria study is here presented. We were able to determine the cause/manner of death in $63.8 \%$ of exhumed bodies within a mean post mortem interval of 49.17 days. We conclude by agreeing with Breitmeier et al. (2005) who opined that an exhumation can answer a number of questions and help the justice system, although by consensus, the success of an individual exhumation cannot be predicted. Hence, whenever the need arises, EPME should be done.

\section{Abbreviations}

EB: Exhumed body; EPME: Exhumation and post mortem examination; PME: Post mortem examination

\section{Acknowledgements}

All the staff of medicolegal unit of the police clinic.

\section{Adherence to national and international regulations}

Not applicable

\section{Authors' contributions}

Both AWO and NCC did the EPME and conceptualized and design the work. Both authors analyzed/interpreted the data and drafted the manuscript. All authors read and approved the final manuscript.

\section{Funding}

This research received no specific grant from any funding agency in the public, commercial, or not-for-profit sectors.

Availability of data and materials

Autopsy registers and autopsy reports of the police clinic.

\section{Ethics approval and consent to participate}

Ethical approval was obtained from the University of Uyo Teaching Hospital ethical committee (UUTH/AD/S/96/VOL.XXI/251).

\section{Consent for publication}

Not applicable

\section{Competing interests}

The authors declare that they have no competing interests.

\section{Author details}

${ }^{1}$ Department of Histopathology, University of Benin Teaching Hospital, Benin City, Edo State, Nigeria. ${ }^{2}$ Department of Pathology, University of Uyo, Uyo, Akwa Ibom State, Nigeria.

Received: 13 August 2019 Accepted: 2 December 2019

Published online: 23 December 2019

\section{References}

Agarwal A, Nizamani S, Mouhammed HAD (2017) Whether dead men really do tell stories - a study on tales from the graves. J Med Toxicol Clin Forensic Med 3(2):7-12

Ammani J, Sudheer S, Roopesh T (2016) Analytical study of exhumations and its medico-legal importance. Int J Contemp Med Res 3(4):972-975
Asad, Hadyat-ur-Rehman, Yasmin, Hamid A (2014) The causes of death on exhumation in Pakistan. Med Forum 25(7):32-35

Bardale R, Ambade V, Dixit P (2012) Exhumation: a 10-year retrospective study. J Indian Acad Forensic Med 34(2):143-145

Breitmeier D, Graefe-Kirci U, Albrecht K, Weber M, Tröger HD, Kleemann WJ (2005) Evaluation of the correlation between time corpses spent in inground graves and findings at exhumation. Forensic Sci Int 154(2-3):218-223

Cordner S, Coninx R, Kim H, Alphen D, Tidball-Binz M (2016) Temporary storage of dead bodies. In: Cordner S, Coninx R, Kim H, Alphen D, Tidball-Binz M (eds) Management of dead bodies after disasters: a field manual for first responders. 2 Ed Pan American Health Organization, Washington, DC, pp 23-25

Faduyile FA, Taiwo OJ, Soyemi SS, Akinde OR (2015) Exhumation- providing justice to victims of homicide: the Nigerian experience. Nig Q J Hosp Med 25(2):866-889

Guimarães MA, Francisco RA, Evison M, Iwamura ESM, Machado CEP, Alves da Silva RH et al (2017) Procedural and political aspects of forensic exhumation in Brazil. Human Remain Violence 3(1):37-51

Hanzlick R, Hunsaker JC, Davis GJ (2002) A guide for manner of death classification National association of medical examiners:Savannah, MO pp 1-39.

Karger B, de la Grandmaison GL, Bajanowski T, Brinkmann B (2004) Analysis of 155 consecutive forensic exhumations with emphasis on undetected homicides. Int J Legal Med 118(2):90-94

Kremer C, Sauvageau A (2008) Legally interred and unlawful burials: a retrospective study of exhumation cases in the province of Quebec, Canada. The Open Forensic Sci J 1:16-18

Kumar K, Pirzada GS, Chand H, Abbasi KA, Shaikh SA, Shaikh MR (2011) Frequency of unascertained cause of death in exhumed bodies: multicentric experience in interior of Sindh. P J M H S 5(4):613-616

Nnoli MA, Nwabuko CO, Ebughe GA, Omotoso AJ (2013) Exhumation-abduction with violent death in South Eastern Nigeria from 2007-2011. IOSR J Dent Med Sci 6(4):56-58

Nouma Y, Amar WB, Zribi M, Bardaa S, Hammami Z, Maatoug S (2016) Forensic examination after exhumation: contribution and difficulties after more than thirty years of burial. J Forensic Legal Med 44:120-127

Saukko P, Knight B (eds) (2004) Exhumation, the forensic autopsy, 3rd edn. Hodder Arnold, UK, pp 36-39

Sprogøe-Jakobsen S, Eriksson A, Hougen HP, Knudsen PJT, Leth P, Lynnerup N (2001) Mobile autopsy teams in the investigation of war crimes in Kosovo 1999. J Forensic Sci 46:1392-1396

Wikipedia. 2018 Grave. http:// en.wikipdia.org/wiki/grave accessed 21/10/18

Williams EJ, Davison A (2014) Autopsy findings in bodies repatriated to the UK Med Sci Law 54(3):139-150

\section{Publisher's Note}

Springer Nature remains neutral with regard to jurisdictional claims in published maps and institutional affiliations.

\section{Submit your manuscript to a SpringerOpen ${ }^{\circ}$ journal and benefit from:}

- Convenient online submission

- Rigorous peer review

- Open access: articles freely available online

- High visibility within the field

- Retaining the copyright to your article

Submit your next manuscript at $>$ springeropen.com 